\title{
The Reconstruction of Buddhist Landscape Planning of Kagyu Samye Ling Monastery in Scotland
}

\author{
Xin Li, Pinlei Ma, Xiuyao Ma \\ School of Art, Shandong Jianzhu University, Jinan 250101, China;
}

\begin{abstract}
By comparing the differences in the Buddhist landscape between Scottish Kagyu Samye Ling Monastery and the Samye Ling Temple in Tibet, the article points out the former has three problems such as an inadequate Buddha-Hall, unbalanced distribution of Buddhist landscapes and incomplete Mandala landscape pattern. It is proposed that to enlarge Buddha-Hall and build out corridors for more circumambulations, and to construct new landscape in four directions to form a complete Buddhist pattern including Dvipa and Eight Small Continents. The conclusion is the reconstruction of Kagyu Samye Ling Monastery in Scotland brings new spatial distinction, which will enhance its influence and sustainable development.So the modernity method of Tibetan Buddhist temples overseas is based on the inheriting the traditional Tibetan Mandala Buddhist pattern, and then to develop the Five-Holy style Buddhist landscape pattern which inculturation with the native site situation.
\end{abstract}

\section{A brief introduction of Kagyu Samye Ling Monastery in Scotland}

In 2001, there were 7,000 Buddhists in Scotland, just over half were British whites whose parents were non-Buddhists, and the next largest group was Chinese. In 2011, the number of Buddhists in Scotland increased to 13,000 , accounting for $2 \%$ of the Scottish population. Kagyu Samye Ling Monastery in Scotland was built since 1967 and dedicated in 1988, and it gradually became the largest Buddhist temple in Europe. Western whites converted to Buddhism on a large scale are relevant to the anti-war trend of thought and related movements bursted in 1967, and also influenced by the prevalence of Buddhism among British bands and hippies. According to the official records in the early days among the thirty-one Buddhist monks, nineteen were Tibetans, seven were English, two were French, and there were one Scottish, one Dane and one Dutch woman.

The Kagyu Samye Ling Monastery is situated in a level ground by the River Esk in the southwestern valley in Scotland. Due to traffic and management inconvenience, several non-mainstream denominations had hidden here and left their own religious landscape. For example Convanters Martyr Andrew Hislop was shot here and left a poignant gravestone, and the once shot lodge Johnstone House became something of celebrity magnet because of preaching Buddhist Sutras. On the contrary, the Davington church built by the Reformed Presbyterian now is a cowshed. That Tibetan Buddhist temple can grow and develop in this remote valley is benefit from their space strategies that changing for survival. The first strategy is to sacrifice part of the space pattern of traditional Tibetan Buddhist temple and choose to construct in stages. The second is to change the missionary methods by using multilingual verses to teach, such as in English, Tibetan and Chinese. The third is converting a lot of music bands and hippies to be Buddhists in spite of their coming also bring a bad reputation to the temple, but the conversion did to promote the process of inculturation of Tibetan Buddhism. The fourth is reshaping the image of Tibetan Buddhism with colorful Buddhist buildings, white pagoda and so on. The fifth is adopting the South Asian Buddhist landscape symbols innovatively. The sixth is according to the new Buddhist landscape to offer new worship route for Buddhists. The seventh is teaching Buddhist doctrines, routine, yoga, meditation and Tai Chi classes through advertising and notices on the Internet to attract Buddhists from all over the world. 

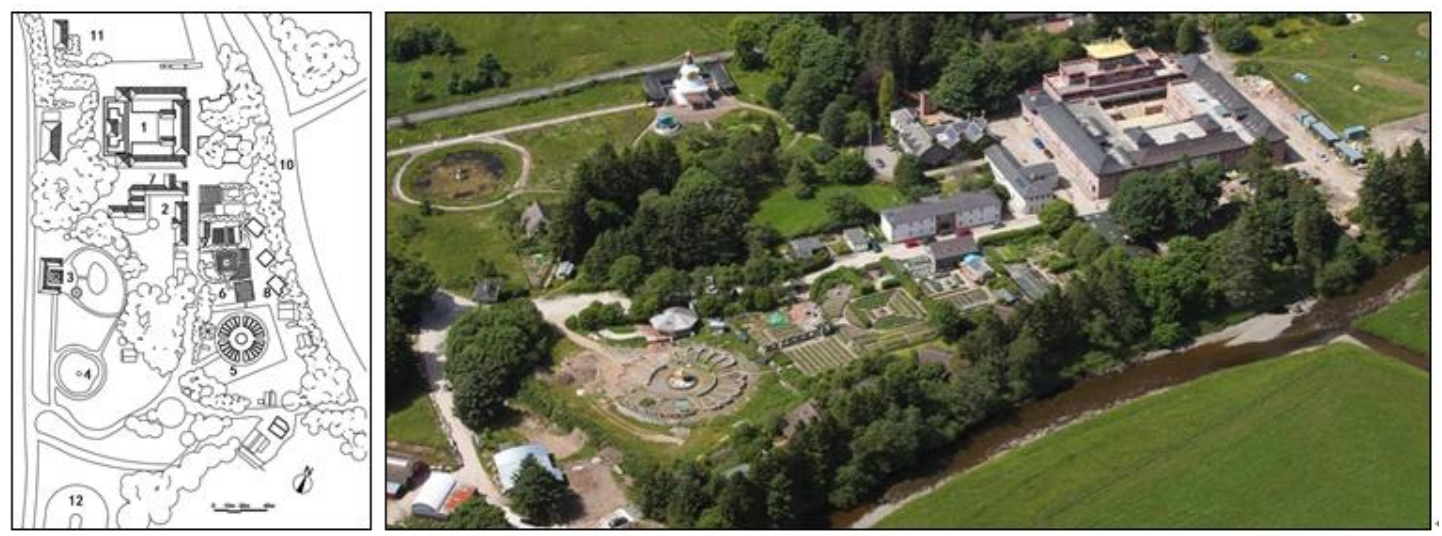

a.The planning of Samye Ling Monastery in Scotland; b. A bird's eye view of the present situation of Samye Ling Monastery; 1.Buddhist Temple; 2.Johnstone House; 3.White Stupa; 4. Nagarjuna Statue; 5. Green Tara Tibetan Herbal Medicine Garden; 6. Organic Herb and Vegetable Farm; 7. Abbot's office; 8.Cabin Guest House; 9.Tibetan Tea and coffee Room; 10. River Esk; 11.Camp Site; 12.Parking lots;

Figure 1. The present situation of Samye Ling Monastery in Scotland

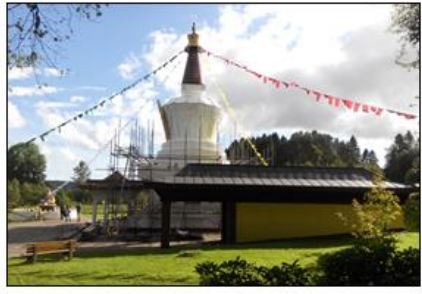

a.White Stupa and Circumanbulation;

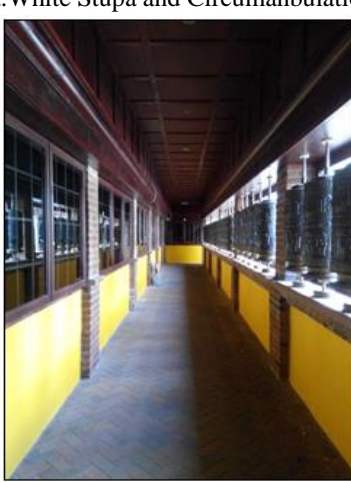

d. The Prayer Wheel House;

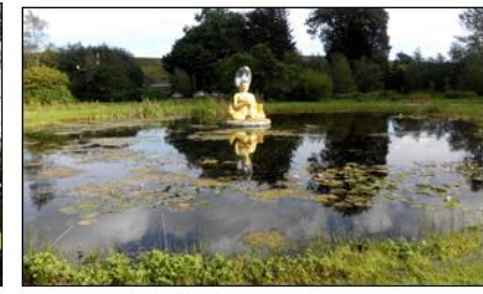

b. Nagarjuna Statue and pond

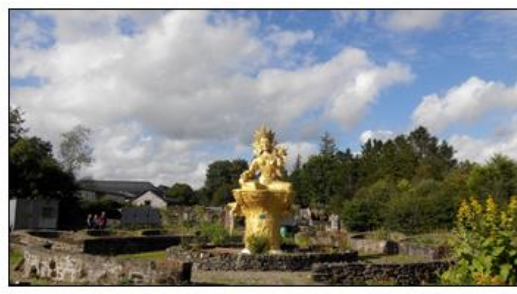

c. Green Tara Tibetan Herbal Medicine Garden;

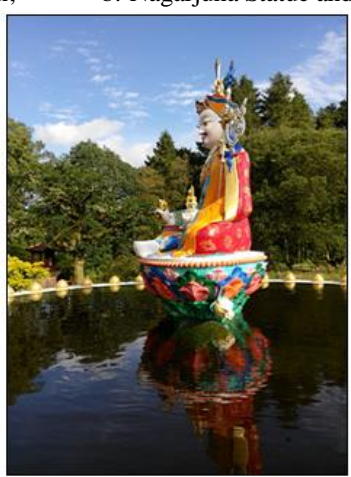

e. Guru Rinpoche Statue;

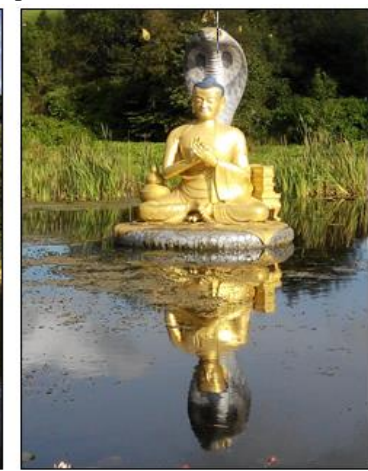

f. Nagarjuna Statue;

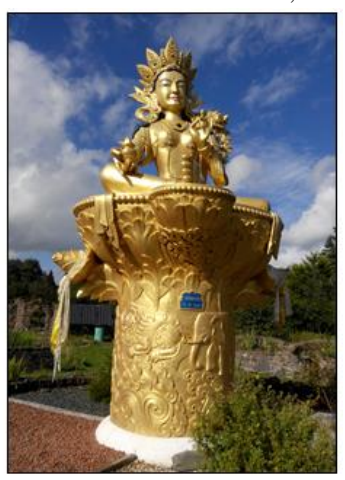

g. Green Tara Statue;

e. Guru Rinpoche is known as "The Lotus Born" who was born spontaneously from a lotus flower, and he introduced Buddhism to Tibet. Now his statue sits in the pond at the foot of the White Stupa.

f. Nagarjuna was a 2nd Century Indian saint who brought together several strands of Buddhist philosophy which today are followed by the kagyu tradition to which Samye Ling belongs.

g. Tara is considered to represent the goddess of unlimited love and compassion for the world in Tibet. It also has been recognized by European especially in Gaelic culture. The statue is surrounded by four groups of petal-like stone beds planted a variety of Tibetan herbals;

Figure 2. Buddhist Landscape of Samye Ling Monastery in Scotland

The Buddhist Monastery along the river has magnificent scenery, and from north to south it plans the camp site, Buddhist Temple, Buddhist landscapes, cabin guest houses, parking lots and so on. The atrium-style Buddhist temple incorporates Buddha Hall, Abbot's office, Dinning Hall and Lecture Hall are basically completed, as well as the southern garden (Figure 1). However, there is no Buddhist landscape in the east, west and north direction till now. The southern landscape includes free-style water landscape such as pagodas, Buddhist statues, island and bridge, as well as regular-style gardens which plant Tibetan herbals, grapes, cacti and vegetables. It's main Buddhist landscapes are White Stupa and Prayer Wheel House, Nagarjuna Statue and pond in the southwest, and Green Tara Tibetan Herbal Medicine Garden in the southeast (Figure 2). 


\section{Problems and suggestions to Samye Ling Monastery in Scotland}

\subsection{Budda Hall space is narrow and needs to be enlarged}

Budda Hall of Samye Ling Temple in Tibet is a centralized layout, which consists of the main hall, the inner corridor and the outer corridor, forming several narrow worship paths between the high walls (Figure 3a, $3 b)$. On the contrary, the Tibetan temple in Scotland is an atrium-style building, arranging the rectangular Budda
Hall located on the second floor of the West Wing (Figure 3c, 3d). Usually Budda Hall is divided into three parts: north, middle and south. When Dharma assembly is held, all partitions are removed to form a unified space and the spatial hierarchy is progressive (Figure 3e, 3f). It is proposed to reshape a centralized Budda Hall through covering the inner courtyard to increase the area and build out a double layer Circumanbulations surrounding outer wall. Meanwhile, to build out a north entrance to connect with the northern landscape. The space hierarchy of Budda Hall would be coincided with Tibetan Buddhist temples, which have a central space guarded by constructions both in four directions.

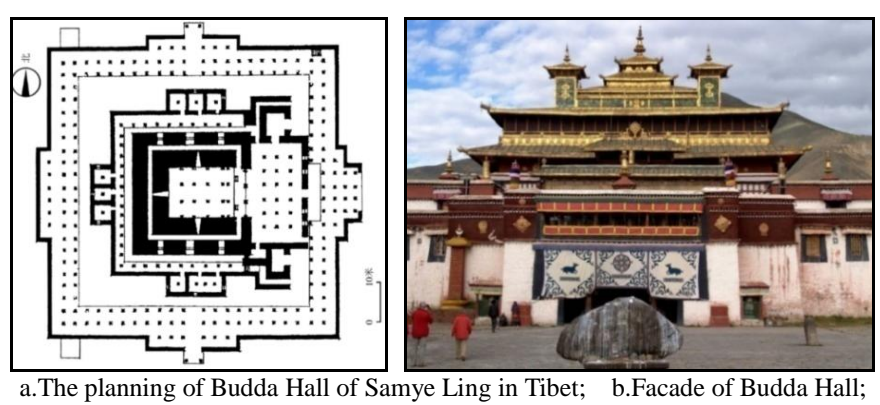

The form and Budda statues of the three-story building are different respectively, like the first floor is Tibetan, second floor is Chinese and third floor is Hindu

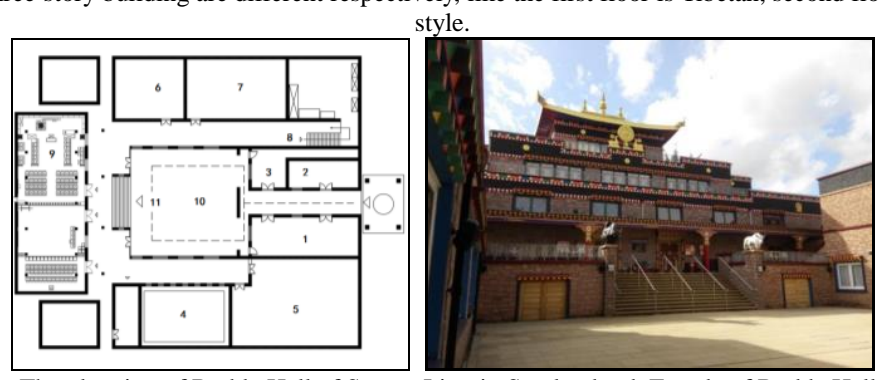

c.The planning of Budda Hall of Samye Ling in Scotland; d. Facade of Budda Hall

c.1.Exhibition Hall; 2.Accommodation Check in; 3.First Aid Point; 4.Dinning Hall;

5.Workshop; 6. Library; 7.Lecture Hall; 8.To the second floor; 9.Budda Hall; 10. Courtyard. 11.To the Budda Hall on second floor;

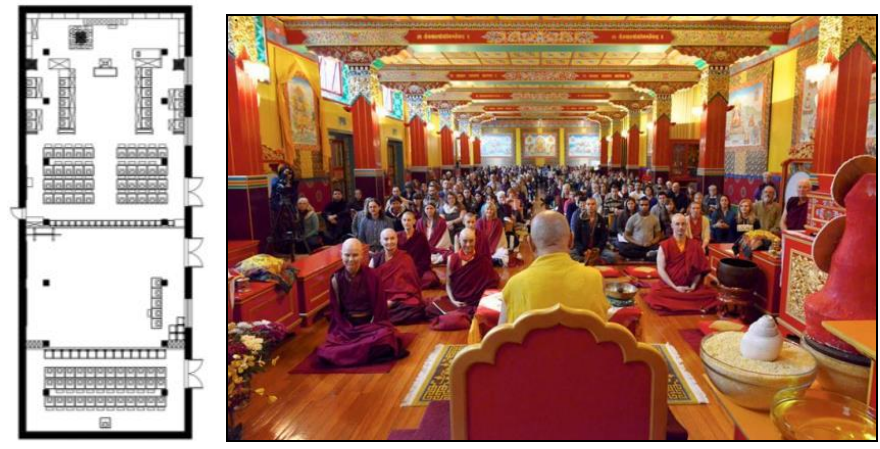

e. The planning of Buddha Hall; f. The interior view during Dharma assembly;

e. The North room is decorated with Buddhist shrines and Thousand-Buddha Wall, serving as the Most Holy Place. Monks occupy half of the space and rest are furnished meditation futons and rugs. The middle room is a house of learning Sutra as the Holy Place, which has several rugs, futons and a mobile Thangka. The southernmost room is usually as yoga class serving as the Secular World.

Figure 3. The Comparison between Budda Hall of Samye Ling in Tibet and Scotland

\subsection{Perfecting the Quartet Buddhist Landscape}

The problems of the southern landscape include the lack of a central landscape, the central points of both Nagarjuna Statue and Green Tara Tibetan Herbal Medicine Garden are irregular on location and distance.
Meanwhile, the oversize independent White Stupa seems like more significant than other Buddhist landscape. In the north, a group of architecture including courtyards and pavilions should be constructed as a Buddhist educational building. In the east and as well as west, waterscape should be built out as the central landscape, 
which is surrounded by Tibetan Herbal bed and vegetable gardens to offer more worship paths. Using a front pavilion and a square covered corridor behind to guard the central waterscape. In order to highlight the east-west axis, two outdoor meditation gardens should be constructed at both ends of the extended line.

\subsection{The Reconstructing of Buddhist Landscape Pattern of Samye Ling Monastery in Scotland}

\subsubsection{Problems of Five-Holy Style Pattern of the Buddhist Monastery in Scotland}

The landscape feature of Tibetan Buddhist temple is Five-Holy Style which consists of "Cross-axis, inner circle, four sub-circles and a ring." For example Mingxin Huang believed that "Abhidharma-kosa" influenced the planning of Samye Ling Temple in Tibet, "The eastern buildings are all half-moon shaped, the southern buildings are all shoulder-bone shaped, the western buildings are all oval shaped and northern buildings are all square shaped." Lots of structures have been destroyed only central Budda Hall and Four-color Towers stand still fortunately. Its Five-Holy style pattern is obviously identifiable. The cross-axis rotates slightly clockwise and the innermost circle covers the Budda Hall. The center points of Dvipa all situated on the inner edge of the ring although Eight Small Continents are not survival from the destruction. The lines connecting the center points of Four-color Towers form a square shaped, and the outer edge of the ring basically coincides with enclosure walls and so on (Figure 4a). The masterpiece that imitates Tibetan Samye Ling is Hebei Puning Temple in Central China. The site is well-organized and structures' shape is more coincide with the description of "Abhidharma-kosa". Such as the eastern Purvavideha is a semicircle shaped and the southern Jambudvipa is a trapezium shaped. The western Aparagodaniya is oval shaped and the northern Uttarakuru is a square shaped. Five-Holy style pattern is represented by the counterclockwise rotated cross-axis and the innermost circle covers storied building of Mahayana. The center of the four sub-circles is accurately positioned on the inner edge of the ring, and the Four-color Towers both occupied the square's corner, etc. (Figure 4b). In contrast, Samye Ling Monastery in Scotland has only the innermost circle and part of southern Jambudvipa (4c). It should complete four sub-circles (Dvipa) to perfect Five-Holy Style Buddhist landscape pattern. In order to remain existed Buddhist landscape, the center of the southern sub-circle needs to be moved forward to the outer edge of the ring. The two sub-circles in the east and west should be tangent to the inner edge of the ring, and new-built three towers should be squared with White Stupa (Figure 4d).

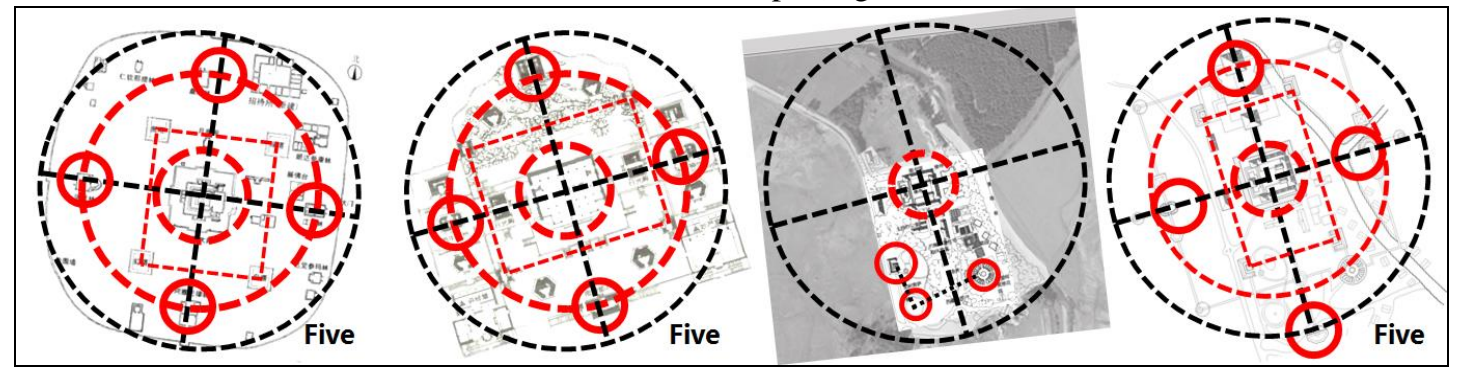

a. Samye Ling Temple in Tibet which had integrated into Tibet is the prototype of the Five-Holy Style pattern;

b.Hebei Puning Temple in China had developed a Chinese Tibetan temple, having a typical Five-Holy Style pattern; c.Samye Ling Temple in Scotland which had not yet developed a complete Buddhist Landscape pattern; d.Conceptional Planning of Scottish Samye Ling Monastery in Scotland has a Five-Holy Style Buddhist Landscape pattern.

Figure 4. The Comparison of Five-Holy Style Buddhist Landscape pattern among three Tibetan Buddhist Temples

\subsubsection{Suggestions for reconstructing Five-Holy Style Buddhist landscape pattern in Scotland}

Based on existed Buddhist landscape, it is suggested that to construct four Dvipa, Eight Small Continents and Four-color Towers to offer more systematic worship path to believers to walk around and reflect. For instance to build a trapezoidal pond decorated by a flower bed in southern. The statue of Nagarjuna and Green Tara can be considered as belong to Eight Small Continents. And to pave the ground along the axis to reshape southern Jambudvipa. In the northern to construct a square-shaped library and colleges of Buddhism which encircling rectangular courtyards and two symmetrically pavilions which form the northern Uttarakuru. In the eastern a semi-circular pond surrounded by Tibetan Herbal beds offer a Tibetan medicine treatment and outdoor meditation space to reshape the eastern Purvavideha, building two pavilions in the front and back as two of

Eight Small Continents. Taking advantage of the western slope to build an oval-shaped pond and garden planting vegetables and Tibetan herbals on terrace, together with the front and rear pavilions to rebuild the western Aparagodaniya. More importantly, to construct supplementary three-color towers according to the form of southwest White Stupa symmetrically. Such as the southeast Red Stupa, the northwest Green Stupa and the northeast Black Stupa. At both ends of the east-west axis to build out an open ring-shaped meditation garden, then using a circular paving to confine the temple's scope at the four corners (Figure 5). 


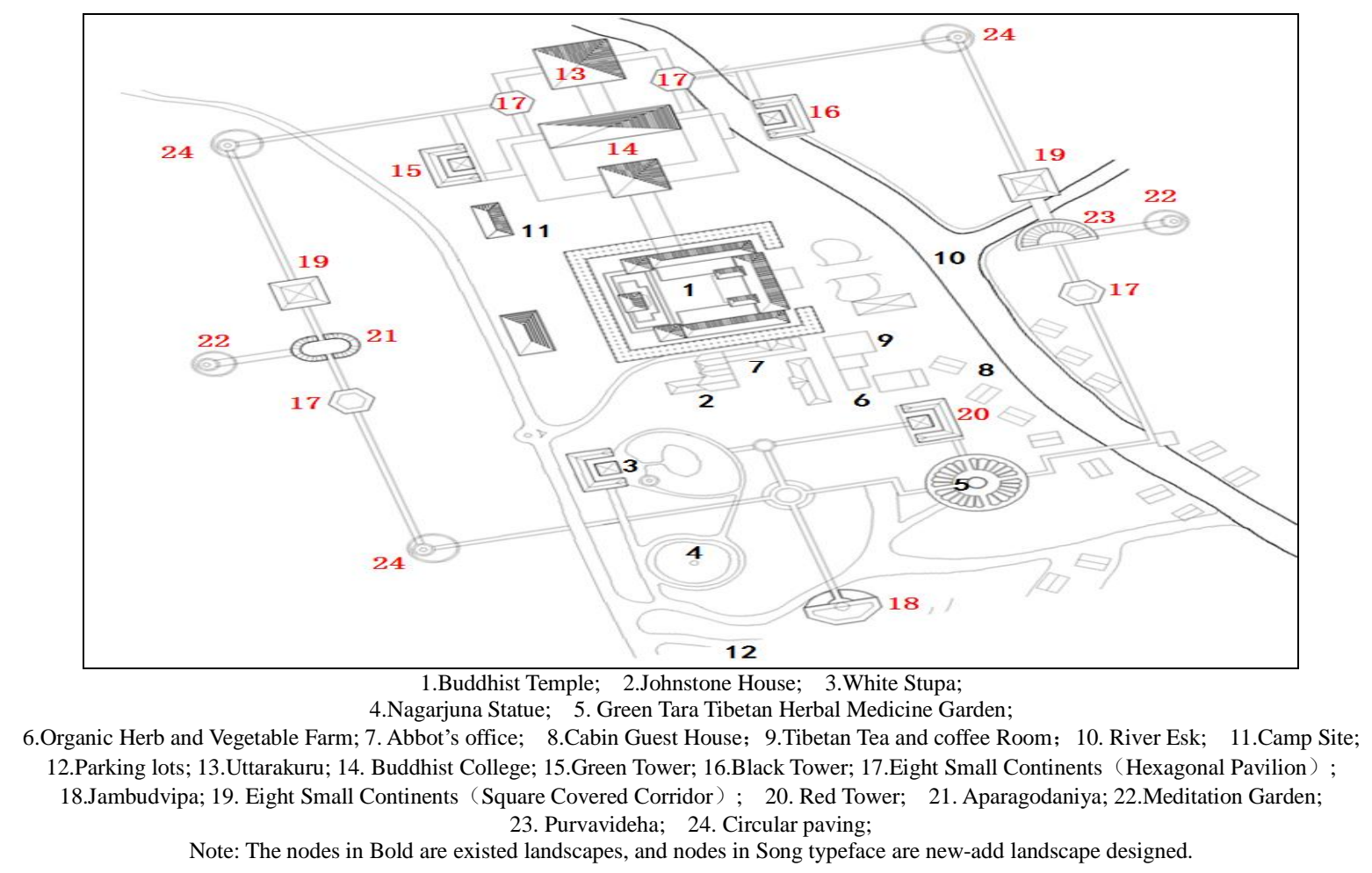

Figure5. Conceptional Planning of Samye Ling Monastery in Scotland

\section{Conclusion}

Depending on the user's identity and the space they can access to classify the sacred grade, the central Budda Hall of the Samye Ling Temple in Tibet and Hebei Puning Temple in China is the first level, Dvipa is the second level and the Eight Small Continents are the third level. Four-color Towers are the fourth level and the others are the fifth level (Figures 6a, 6b). The Scottish Buddhist Monastery landscape is imperfect due to land right, budget and overlong construction period. The Buddhist landscape is concentrated in the south and not a Mandala Pattern of the Mount Meru is guarded by Divpa, resulting in the worship paths and the spatial hierarchy are immethodical (Figure 6c). In new conceptual
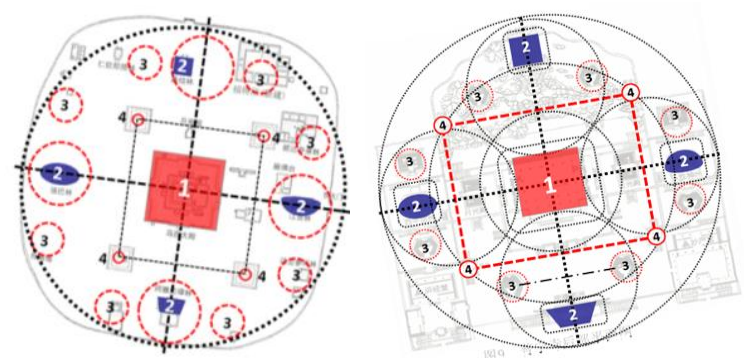

a. Samye Ling Temple in Tibet; b.Hebei Puning Temple in China; c.Samye Ling Monastery in Scotland; d.Conceptional Planning of Samye Ling Monastery in Scotland

planning of Samye Ling Monastery in Scotland the Budda Hall ranks the first, the Divpa (Waterscapes in four directions) ranks second, Eight Small Continents (Pavilions and covered Corridors) are the third, Four-color Towers are the fourth, others are the fifth (Figure 6d). All of them had reshaped a complete Five-Holy Style Buddhist landscape pattern and having organised methodical worship paths. The reconstructed spatial prominent distinction of Samye Ling Monastery in Scotland will help it stand out from Scottish complex religious ecological environment, so as to obtain far-reaching influence and more sustainable development. So the road to modernity of Tibetan Buddhist temples' landscape abroad is inheriting traditional Tibetan Mandala pattern, while to recreate a Five-Holy Style Buddhist landscape based on local characters of the site.
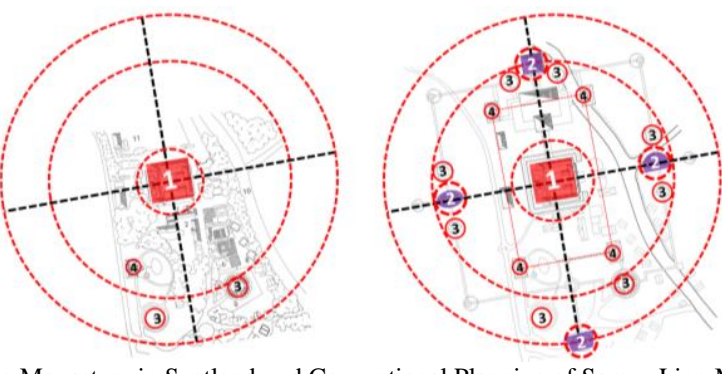

(1. Mount Meru； 2. Divpa； 3. Eight Small Continents; 4.Four-color Towers)

Figure 6. Comparison of the spatial hierarchy and worship paths among Tibetan, Chinese and Scottish Tibetan Buddhist temples 


\section{Acknowledge}

Fund: A Project of Shandong Province Higher Educational Humanities and Social Sciences Program in China, NO: J15WF40.

\section{The source of the pictures:}

1b, from http://www.samyeling.org

3a, from Lima Se's The elements from Indian Buddhism in the architecture of Tibetan monasteries in the 8th and 11th centuries: a case study of the Samye temple and the Tolin temple, page 67;

$3 b$, from http://www.panoramio.com/photo/39313885? source=wa pi\&referrer=kh.google.com;

$4 \mathrm{a}$ and $6 \mathrm{a}$, from Lima Se's The elements from Indian Buddhism in the architecture of Tibetan monasteries in the 8th and 11th century: a case study of the Samye temple and the Tolin temple,page 66, this has been adjusted by author;

$4 \mathrm{~b}$ and 6b, from Dazhang Sun's Puning Temple in Chengde: A Masterpiece of Buddhist Architecture in the Qing Dynasty, this has been adjusted by author;

Note: Other figures are by the author.

\section{References}

1. Steve Bruce. Scottish Gods: religion in modern Scotland, 1900-2012 [M]. Edinburgh: Edinburgh University Press Ltd. 2014

2. Bashir Maan. The New Scots: The Story of Asians in Scotland.Edinburgh[M]. John Donald Publishers Ltd,1998.

3. Lima Se. The elements from Indian Buddhism in the architecture of Tibetan monasteries in the 8th and 11th centuries: a case study of the Samye temple and the Tolin temple $[\mathrm{J}]$. Sichuan Cultural Relics,2012(05):65-71

4. Xin Li. A Study on "Cross-Ring Model" of Scottish Religious Architecture Landscape [J]. Conference Series: Materials Science and Engineering (MSE)(ISSN: 1757-8981)

5. Qu Zha. A Research on Mandala of Samye Ling Temple in Tibet [D] . Tibet University, 2013

6. Dazhang Sun. Puning Temple in Chengde: A Masterpiece of Buddhist Architecture in the Qing Dynasty $[\mathrm{M}]$. Beijing: China Building Industry Press, 2008 